\title{
甲板上に自由水が存在する小型漁船の横摇れの特徵
}

\author{
上野 公彦* · 天下井 清** \\ 木村 暢夫**.岩森 利弘**

\section{Characteristics of Roll Motion for Small Fishing Vessels with Water on Decks}

\author{
Kimihiko UENO, Kiyoshi AMAGAI, \\ Nobuo KIMURA and Toshihiro IWAMORI
}

\begin{abstract}
This paper describes comparison between roll motion when small amount of deck water present and when no deck water.

In most of cases, it is said that a small amount of water on deck acts as a rather effective roll damper and a roll of vessel is less when a small amount of deck water present than no deck water ${ }^{(4)}$.

In our experiments, we recomfirmed the above effect of a small amount of water on deck. However, in our experiments there were some cases that a small amount of water on deck did not act roll damper but encouraged the roll motion. This paper describes those cases from a view point of resonance.
\end{abstract}

\section{1. 緒言}

筆者らは先に小型漁船の横摇れ中の甲板上の滞留水の影響を調べるため、正弦波的横摇れを再現できる 動摇発生装置の上に設置した透明タンク内の水の挙動を観察し、動摇振幅、動摇周期及びタンク内水深の

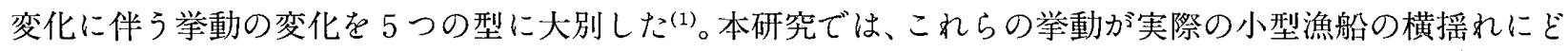
のような影響を及ぼすのかを実験的に調べると共に、自由水が存在する場合としない場合との横摇れの特 徵の比較を行った。

また、筆者らは先に張り出し甲板やハードチャイン等の形状的特徴を有する小型漁船に対しては、自由 横摇れ減衰が動摇振幅に大きく依存することを指摘した。即ち減衰係数が、大振幅時と小振幅時では大き く変化することを鮭鱒流し網漁船の模型船を用いた実験で検証し、横摇れ運動方程式中の減衰項を補正す ることにより同一の係数を用いて減䒾曲線を再現した(2)。今回はこの問題に関し、同様な船体形状を有する 他の漁船についても検討した。

\section{2. 実験}

実験に使用した模型船は小型鮭鱒流し網漁船「北進丸」19.9GTの $1 / 7.6$ 縮尺模型と、「北進丸」と同様に 甲板やハードチャイン等の形状的特徵を有するホタテ養殖船「丸東丸」 $17.7 \mathrm{GT}$ ○ $1 / 11$ 縮尺模型である。線 図を図 1 に示す。表 1 に主要目と自由水が存在しない状態での載貨条件を示す。両船共に甲板上に自由水 が存在する場合と存在しない場合について、静水中自由横摇れ減衰試験 と規則波中動摇試験を行なった。

* 正会員 東京水産大学 (下108 東京都港区港南4-5-7)

**正会員 北海道大学水産学部 (T048 函館市港町3-1-1) 


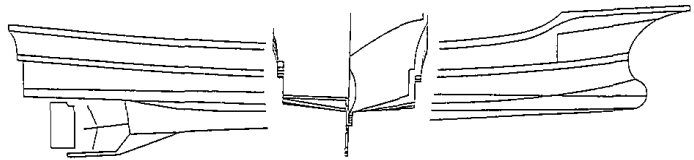

丸東丸 $17.7 \mathrm{GT}$

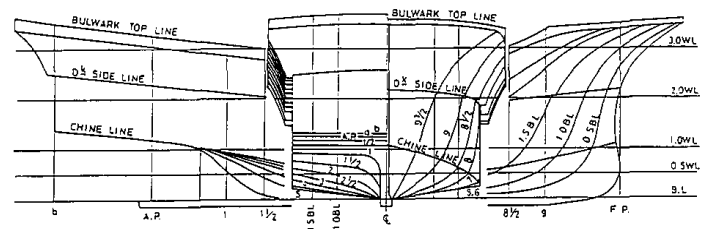

北進丸 $19.9 \mathrm{G} \mathrm{T}$

図 1 線図

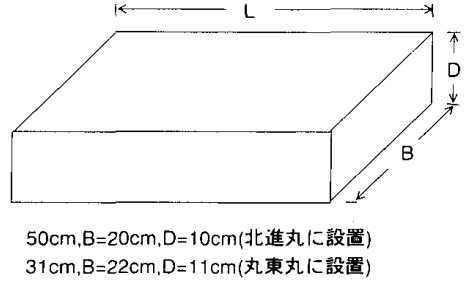

図 2 模型船に設置したタンクの主寸法

模型船の甲板部に設置したタンクに水を 入れることにより甲板上の自由水を仮定 した。設置したタンクの主寸法と設置位 置をそれぞれ図 2 と図 3 に示す。自由水 の存在による見かけ上の重心位置の上昇 量は「北進丸」で約 $1.5 \mathrm{~cm}$ 、「丸東丸」モ デルで約 $0.3 \mathrm{~cm}$ である。

静水中自由横摇れ試験では、静水中で 模型船にある傾斜角を与えた後、その状 態から初速度 $0 て ゙$ 解放し、その後の横摇 れ角変位を模型船上に設置した動摇計に より計測した。規則波中動摇試験では、 模型船を波の進行方向に対して垂直に浮 か心゙、造波装置によって発生させた規則 波によって生じる船体の横摇れ角変位・ 船首摇れ角変位を計測した。静水中自由 横摇れ試験と規則波中動摇試験は共に船 体 6 自由度運動を拘束していない状態で 行った。

以上の実験は全て北海道大学水産学部 大型水理実験水槽で行った。

\section{3. 自由水が存在する場合の横摇れ 減衰の特徵}

自由水の影響を調べるため、タンクを模
表 1 実験状態と主要目

\begin{tabular}{|c|c|c|c|c|c|c|}
\hline & $\operatorname{LDD}[\mathbf{x}]$ & $B[\mathbf{n}]$ & $B(\mathbf{n}]$ & 排水 $\mid[\mathbf{k g v}]$ & $G U[C D]$ & \\
\hline 北造丸（掑㓶船） & 2.00 & 0.500 & 0.195 & 137 & 6. 7 & \\
\hline 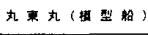 & 1.29 & 0.356 & 0.181 & 65.6 & 3.1 & \\
\hline & $\operatorname{LD} D[M]$ & $B[\boldsymbol{n}]$ & $D[n]$ & \multicolumn{2}{|c|}{ 军胎卜ン致 (GT) } & 主要目的 \\
\hline 北远杂（央船） & 15.2 & 3.80 & 1.48 & \multicolumn{2}{|l|}{19.9} & 流用洴胎 \\
\hline 九柬九（実柏） & 14.2 & 3. 92 & 2.00 & \multicolumn{2}{|l|}{17.8} & タチ殖船 \\
\hline
\end{tabular}

「北進丸」

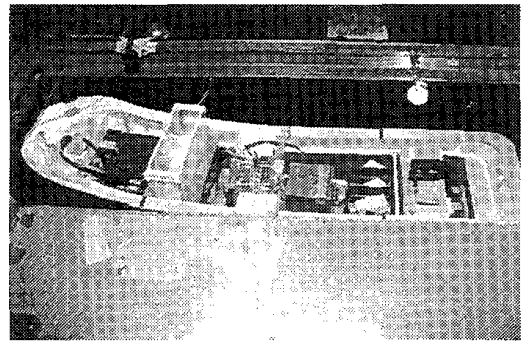

「丸東丸」

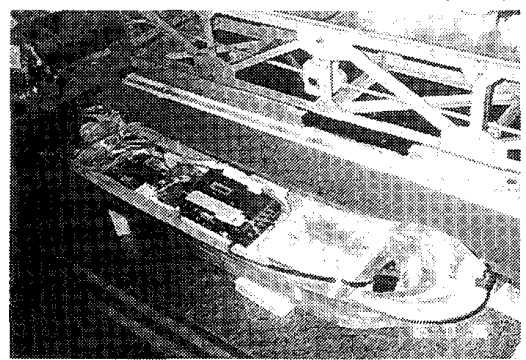

図 3 タンクの設置位䈯
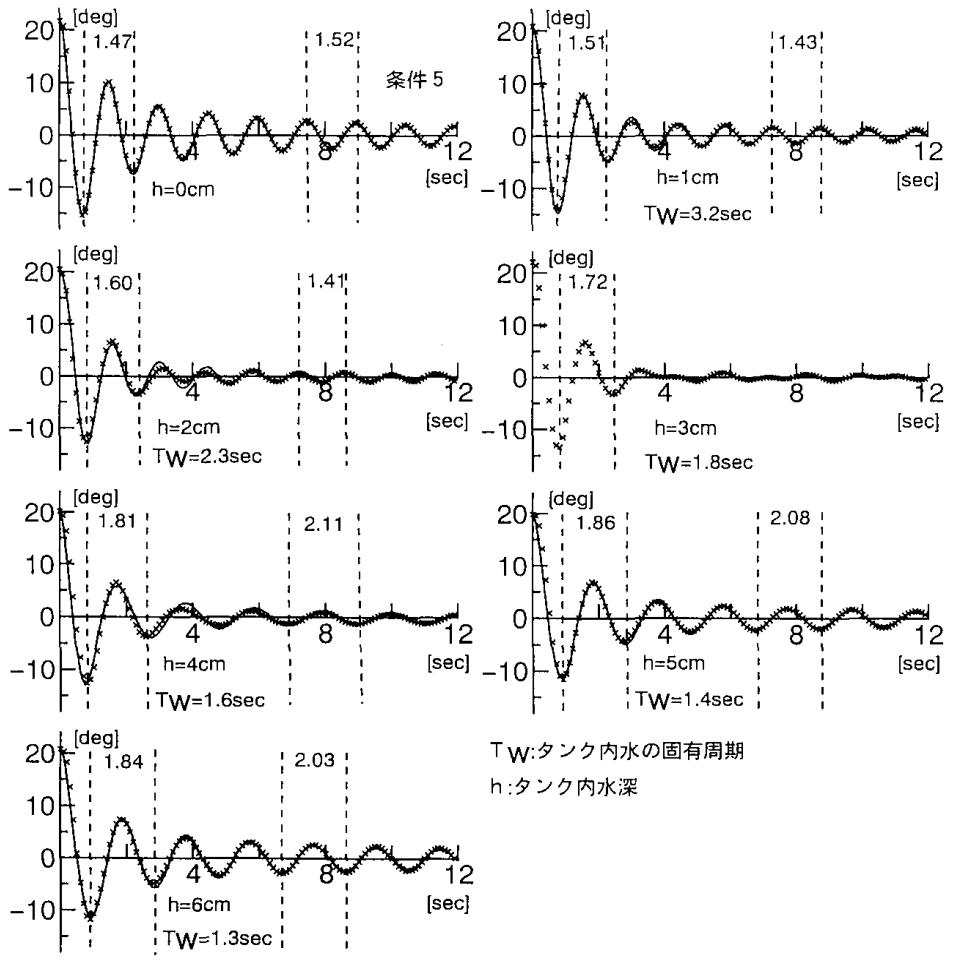

図 4 甲板上に自由水が存在する場合の自由横摇れ減衰曲線 (北進丸モデルに用いた結果) 
型船の甲板部に設置し、自由横摇れ試験を行った。これに よりタンク内水の固有周期と船体の動摇周期との関係を調 べた。また甲板上に自由水が存在する場合、1 自由度横摇 れ運動方程式の右辺は 0 とならないが、見かけ上左辺の係 数が変化するという仮定の基で、自由水が存在しない場合 と同様な運動方程式(1)を用いて横摇れ減衰の現象が表現可 能かを確かめた。減衰項は減衰曲線の特徵を考虑して補正 したものである(2)。

$$
\ddot{\phi}+b_{2}|\quad| \dot{\phi}\left|-b_{5} \dot{\phi}^{4}\right| \dot{\phi}+c_{1} \phi+c_{3} \phi^{3}=0
$$

図 4 に示されるように、初期の船体動摇周期とタンク内 水の固有周期が近い水深 $3 \mathrm{~cm}$ 場合減摇効果が最も大きか った。

タンク内水の固有周期と船体動摇周期の関係では、タン ク内水の固有周期が 小振幅時の船体動摇周期よりも長い、 タンク内水深が、 $1 \mathrm{~cm}$ と $2 \mathrm{~cm}$ 場合、船体動摇周期は振幅 が減少すると共に短くなる傾向を示し、(1)式の復原項は軟 化スプリング型 $\left(c_{3}<0\right)$ となった。これに対して、タンク内 水の固有周期が振幅時の船体動摇周期より当短い、タン ク内水深が $4 \mathrm{~cm} 、 5 \mathrm{~cm}$ そし $6 \mathrm{~cm}$ の場合については自由水 が存在しない場合と同じく、船体の動摇周期は振幅が減少 すると共に長くなる傾向を示し、(1)式の復原項は硬化スプ リング型 $\left(c_{3}>0\right)$ となった。(図中×が実験值、実線が推定 值を示す)

\section{4 、規則波中動摇試験}

\section{1 甲板上自由水と強制波の同調の影響}

本節では「北進丸」モデルを用いた結果について論じる。 図 5 は甲板上に自由水が存在する場合と存在しない場合の 動摇振幅を比較したものである。横軸にはタンク内水深、 縦軸にはタンク内水深が $0 \mathrm{~cm}$ の場合の平均振幅で、各々の タンク内水深の場合の横摇れ解振幅を除した值を示してあ る。即ち図中の $\phi / \phi_{0}=1$ 表わす点線よりも下に值が示されたと きは自由水による減摇効果が作用していることを示し、他方点線 よりも上に值が示されたときは自由水の存在により動摇が助長さ れていることを示している。

従来報告されているように(4)、多くの場合において自由水による 減摇効果か確認された。

しかし、強制波の周期が、タンク内水の固有周期の $1 / 2$ (二次同 調周期)上りも僅かに短いときに減摇効果が作用せずむしろ動摇が 助長される場合があることが確認された。図 5 に示されるタンク 内水深が $1 \mathrm{~cm}$ 場合がその一例である。この場合に対応する、横 摇れ角变位の時系列を位相を揃えた形で図 6 に示す。

以下このような二次同調周期近傍におけるタンク内水の挙動の 特徴について述べる。

動摇するタンク内の浅水によって生じる波についての研究としては、 吉岡らによる非線形理論が(5 8)が報告されている。この理論によると図

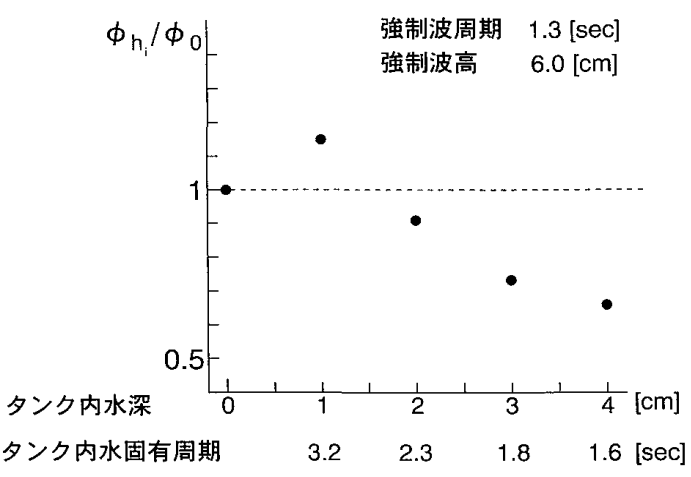

河 5 甲板上に自由水が在する場合としな い場合の動摇振幅の比較

(北進丸モデルを用いた結果)

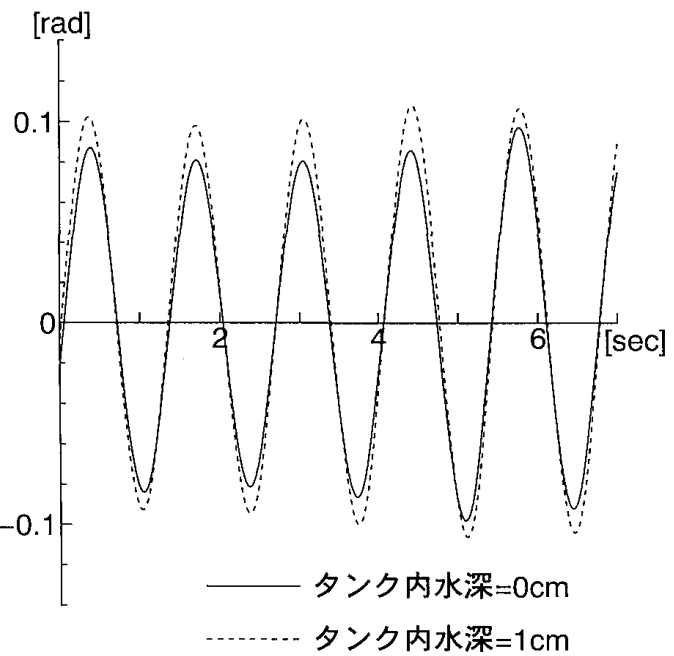

タンク内水固有周期 $=3.2 \mathrm{sec}$ 強制波周期 $=1.3 \mathrm{sec}$

目 6 図 5 で示したタンク内水深が $1 \mathrm{~cm}$ と $0 \mathrm{~cm}$ の 場合の横摇れ角変位の時系列の比較

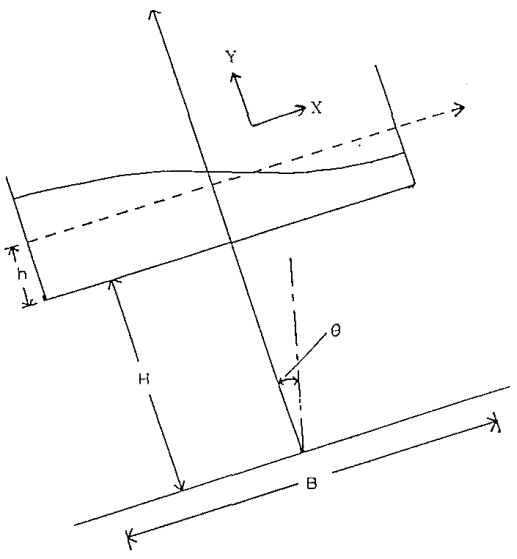

四 7 座標系 
7 のように座標柔および諸変数を設定すると、次の(5)式 で与えられるsの值がー 1 から 1 までの範囲をとる動摇角周 波数帯で段波が生じることが示されている(図 8 )。

$$
\begin{aligned}
& C_{0}=\sqrt{g h} \\
& \omega_{0}=(\pi / B) \sqrt{g h} \\
& \varepsilon=\sqrt{\left(H \omega^{2}+g\right) \theta_{0} /\left(C_{0} \omega\right)} \\
& s=\frac{\pi^{2} C_{0}\left(\omega-n \omega_{0}\right)}{3 B \varepsilon \omega_{0} \omega} \cdot \sqrt{3 B / 8 C_{0}}
\end{aligned}
$$

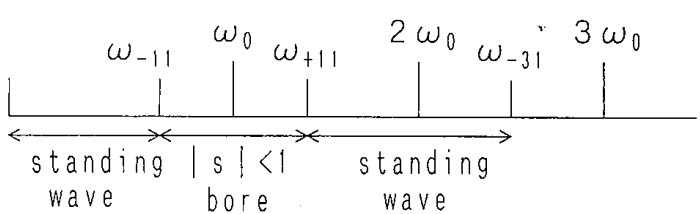

図 8 固有角周波数と限界角周波数 $\left(\omega_{0}\right.$ : 固有角周波数 $)$

$\omega_{0}$ : タンク内水固有角周波数、 $g$ : 重力加速度、 $h$ : タンク内水深、 $\theta_{0}$ ：動摇角振幅、 $\omega$ ：動摇角周波数

(4)式より一次同調周期付近で定常波から段波に変わる限界周波数 $\omega_{-11}$ と二次同調周期付近で段波から再 び定常波に変わる限界角周波数 $\omega_{+11}$ が求められる。

筆者らは先に、限界角周波数 $\omega_{+11}$ を境界としてタンク内水によって生じる波は変化するが、 $\omega_{+11}>2 \omega_{0}$ と なる場合に定常波とはならない場合があることを確認した(1)。即ち、段波から再び定常波に变わるのでなく、 この定常波が再び生じるとされる周波数域で逆方向に進行する二つの遷移波が衝突する現象がみられた。 (段波を含め進行方向に質量輸送を伴うものを以下総称して遷移波と記す)。

図 $9-\mathrm{a} 、 \mathrm{~b}$ はこの一例を示すもので、先に図 5 及び図 6 に示したタンク内水深 $1 \mathrm{~cm}$ の場合に近い動摇状態 を動摇発生装置で起こした結果と、それに対応寸る数値シミュレーション結果である。(今回の実験で用い たものと同じタンクに水を入れタンク内の水深を $1 \mathrm{~cm}$ し動摇台に設置し、周期 $1.3[\mathrm{sec}]$ 、角振幅 5.0 [deg] の動摇を与えた) 数値シミュレーションは次式をMAC法(9 11) とSOLA ${ }^{(12)}$ の手法を基に次式を数值的に解く ことにより行った(1)。

$$
\frac{\partial u}{\partial t}+\frac{\partial u^{2}}{\partial x}+\frac{\partial u v}{\partial y}=-\frac{\partial \phi}{\partial x}+\nu\left(\frac{\partial u^{2}}{\partial^{2} x}+\frac{\partial u^{2}}{\partial^{2} y}\right)+F_{x}
$$
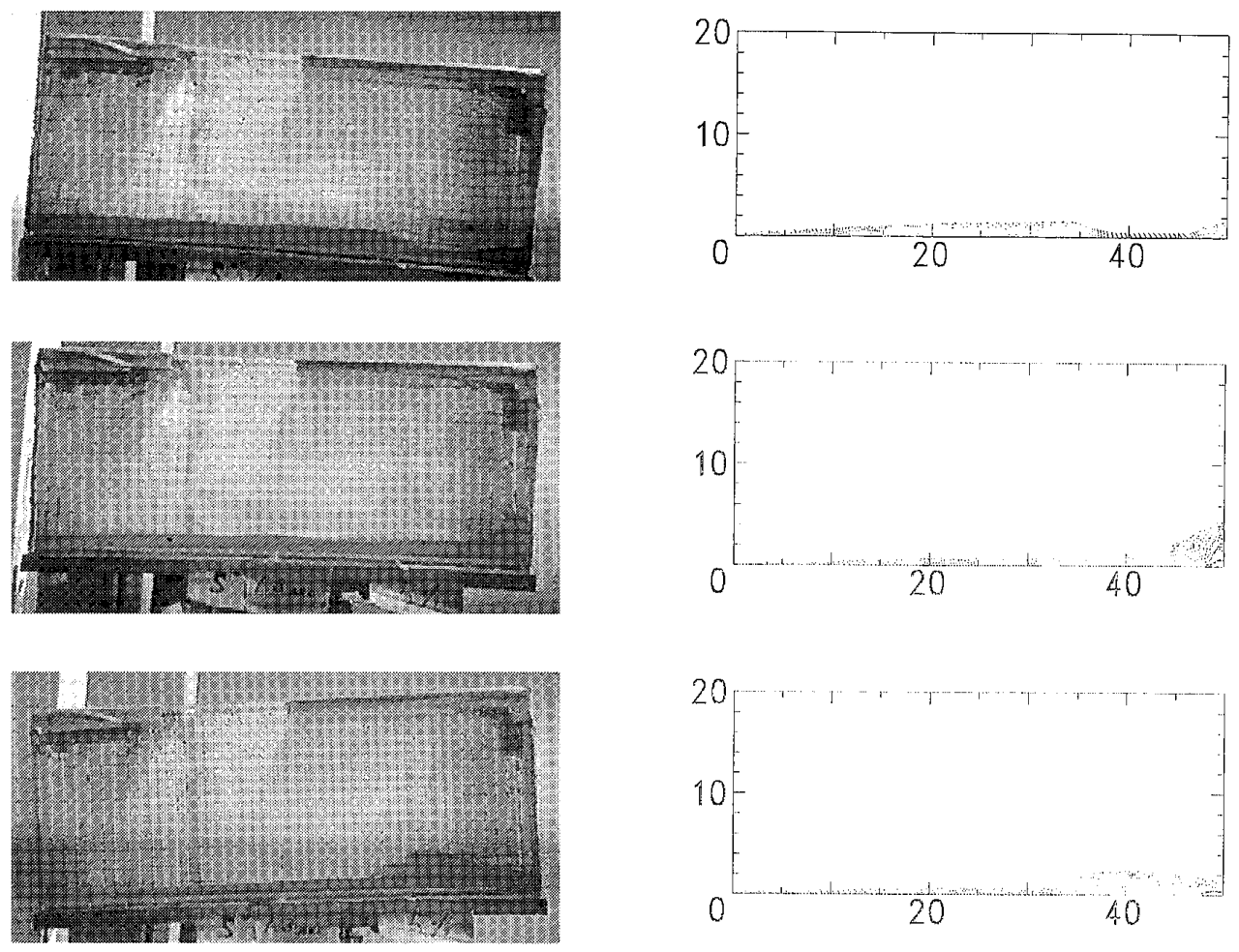

図 9-a 動摇状態(初期) 左：動摇台を用いた結果、右：数值シミュレーション結果 

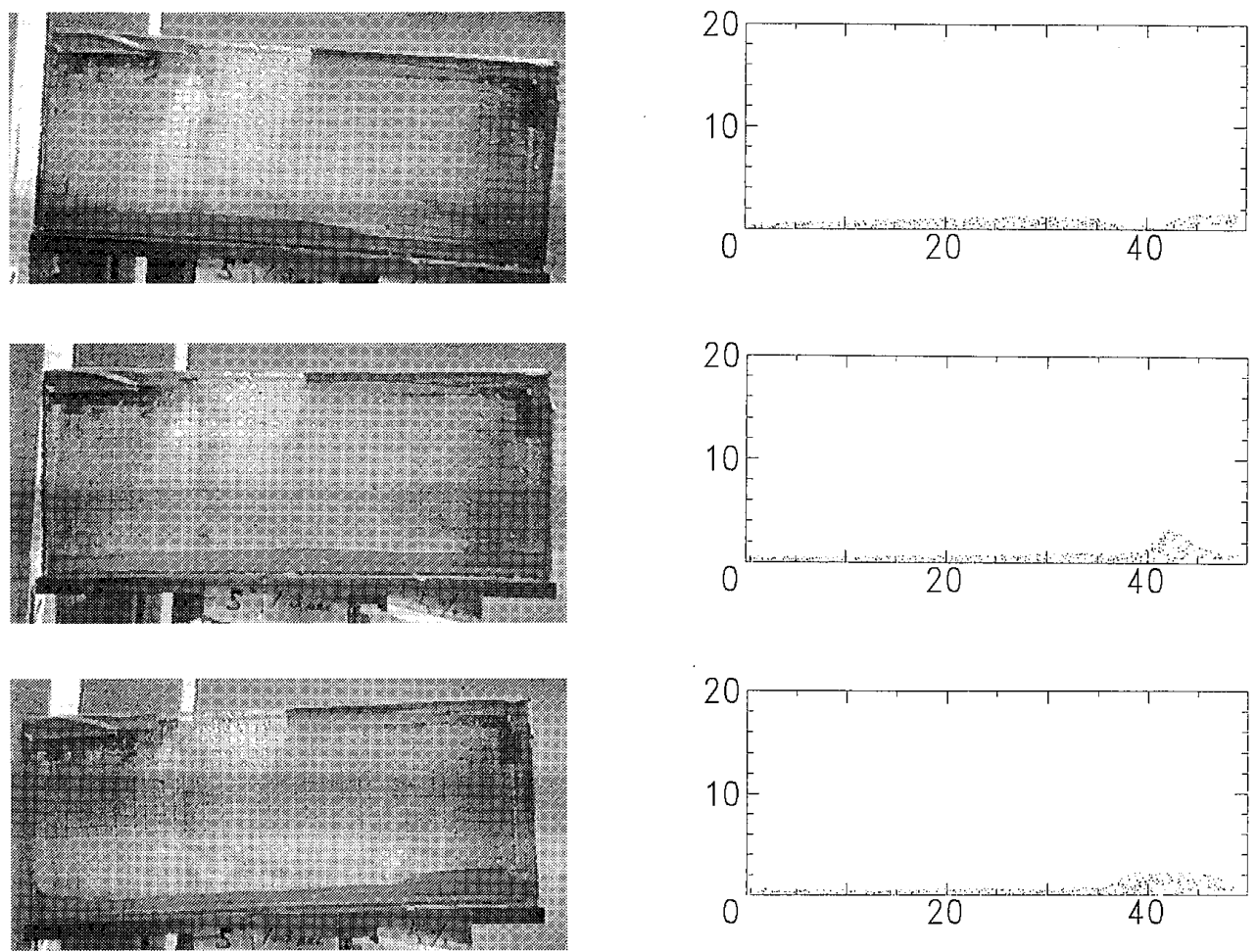

図 9-b 動摇状態(定常状態) 左：動摇台を用いた結果、右：数值シミュレーション結果

$$
\begin{aligned}
& \frac{\partial v}{\partial t}+\frac{\partial u v}{\partial x}+\frac{\partial v^{2}}{\partial y}=-\frac{\partial \phi}{\partial y}+\nu\left(\frac{\partial v^{2}}{\partial^{2} x}+\frac{\partial v^{2}}{\partial^{2} y}\right)+F_{y} \\
& \frac{\partial u}{\partial x}+\frac{\partial v}{\partial y}=0
\end{aligned}
$$

$F_{x}=-g \sin \theta+x \dot{\theta}^{2}+y \ddot{\theta}+2 v \dot{\theta}$

$F_{y}=-g \cos \theta+y \dot{\theta}^{2}-x \ddot{\theta}-2 u \dot{\theta}$

$\theta=\theta_{0} \cos (\omega t+\varepsilon) 、 u 、 v: x 、 y$ 方向の速度成分、 $\nu$ : 動粘性係数、

$\phi$ : 圧力を密度で除した值（座標系は図 7 参照）

図 9-aは動摇初期の過渡的な状態を示していて、このとき一方の段波が他方の段波を側壁側に押し返して いる様子がわかる。しかし図 9-bに示される定常状態に至ると、二つの段波の勢力は均衡し、側壁への押 し返しは緩和されている。

先に図 5 及び図 6 に示したタンク内水深が $1 \mathrm{~cm}$ 場合のタンク内水の場合の挙動も上記と同様な現象で、 逆方向に進行する二つの遷移波が衝突するという特徴を示すものであった。このため強制波の周期が一次 同調周期付近の場合に生じるような激しいスロッシングは緩和され、減摇効果も抑制されたと考えられる。

また吉岡らによって示された限界周波数 ${ }^{(5 \sim 8)}$ は現象の変化を捉えるうえで重要な指標となることが再確認 された。

4.2 甲板上自由水による船体動摇周期の変化の影響

本節で示す結果は「丸東丸」モデルによるものである。前節では甲板上の自由水の固有周期と強制波周 期とに着目して論じたが、本節では甲板上自由水の存在による船体動摇周期の变化そしてそれに伴う強制 波と船体動摇との同調について論じる。

筆者らは先に「北進丸」モデルを用いた静水中自由横摇れ試験で得られたデータに対して、角速度の 1 次式 +2 次式及び角速度の 2 次式のみで表される型の減哀項の減哀係数を推定した結果、減衰係数が初期 傾斜角により変化することを確認した。このため任意の初期傾斜角に対して同一の減衰係数を適用できな いという問題が生じた。そこで減衰項を(1)のように補正し、運動方程式を解くことにより海水流入角に至 るまでの任意の初期傾斜角に対して同一の減衰係数を適用できるようにした(2)。

本研究では、「北進丸」モデルと同様に甲板やハードチャイン等の形状的特徵を有するホ夕テ養殖船「丸 
東丸」の模型船を用い同様な性質が自由横摇れ減衰に おいて生じるかを調べた。

「丸東丸」モデルに和いても「北進丸」モデルの場合 と同様な傾向が確認された。そして、補正した減衰項 を用いることにより、大振幅時と小振幅時で係数を变 化させることなく減衰曲線が再現できた(図10上段)。 図10上段は甲板上に設置したタンク内に水が存在しな い場合の横摇れ減衰曲線である。図10下段はタンク内 に水か存在する場合 (水哚 $4 \mathrm{~cm}$ ) の横摇れ減衰曲線であ る。甲板上に自由水が存在する場合、1 自由度横摇れ 運動方程式の右辺は 0 とならないが、 3 章と同様な仮 定の基で(1)式を推定值の計算に用いた。罒10からも明 らかなように自由水が存在することにより船体の動摇 周期が長くなっている。即ち自由水の存在しない場合 の固有周期は $1.52[\mathrm{sec}]$ (固有角周波数 $4.13[\mathrm{rad} / \mathrm{sec}]$ ) であり、自由水の存在する場合の固有周期は $2.20[\mathrm{sec}]$ (固有角周波数 $2.85 \mathrm{rad} / \mathrm{sec}$ )である。

図11は強制波の角周波数に対する船体の応答横摇れ 角変位を示している。印が自由水の存在しない場合、 口が自由水の存在する場合に対応する。「丸東丸」モデ ルも先に述べた「北進丸」モデルと同様にハードチヤ イン等の船体形状を有しているため、海水流入角に至 るまでの復原力曲線は線形とはならない。従って図 10 からもわかるように動摇周期は動摇振幅とは独立して おらず、動摇振幅が減少すると動摇周期が増加すると いう傾向、即ち硬化スプリング型の傾向を示している。 よって図10の推定值の計算において、運動方程式(1)の 復原項の三次の項の係数は正で近似した。このような 動摇周期 (動摇周波数)の動摇振幅依存性のため、応答 曲線の共振域は、復原力関数が線形な場合に比べ高周 波数側にシフトすることが示されている(12)。印で示し た自由水の存在しない場合ついては、固有角周波数4.

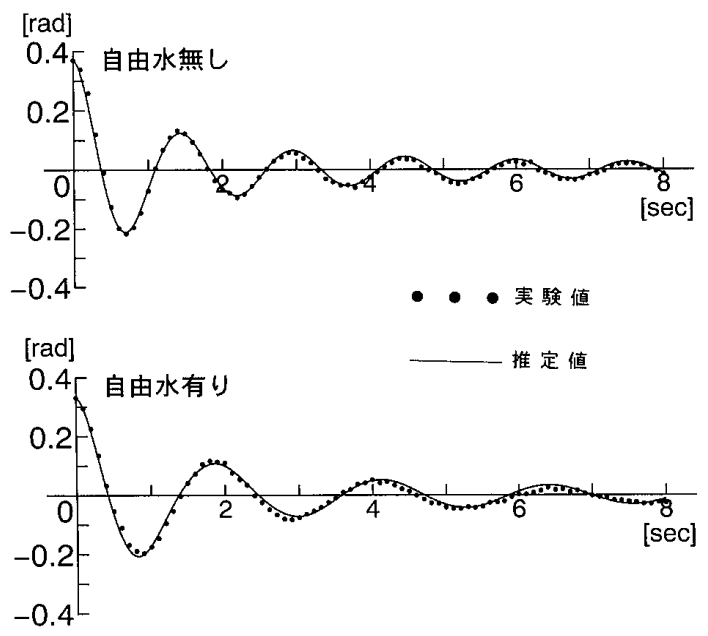

図10 自由横摇れ減衰曲線の比較 (丸東丸モデルを用いた結果)

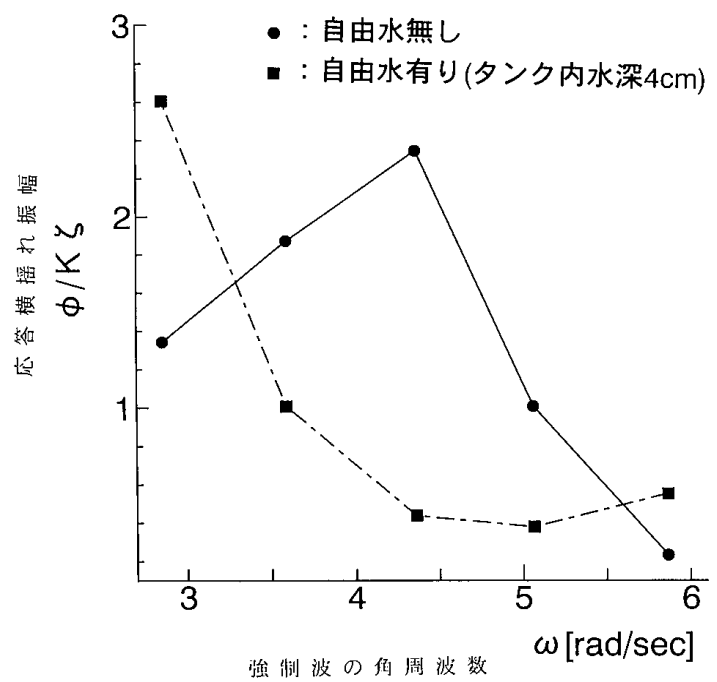

図11 規則波中応答横摇れ振幅

(丸東丸モデルを用いた結果、 $x$ ：波数、 $\xi$ :波高) $13[\mathrm{rad} / \mathrm{sec}]$ 付近で共振域に達してしているが、上記 の復原力の非線形性に起因する振幅応答の傾向がみられる。

自由水の存在する場合の応答振幅の方が、自由水の存在しない場合より大きな值を示したのは図11に示 した $(\mathrm{a}: \omega=2.85 \mathrm{rad} / \mathrm{sec}) の$ 場合と、( $\mathrm{b}: \omega=5.86 \mathrm{rad} / \mathrm{sec})$ の場合である。

まず(a)の場合について述べる。自由水が存在することにより船体の横摇れ固有角周波数が $\omega_{n}=2.85[\mathrm{rad} /$ sec］に変化したため、共振域もこの角周波数近傍に移動している。この状態で船体の横摇れ固有角周波数 に等しい角周波数 $\left(\omega / \omega_{n}=1.00\right)$ の強制波を船体が受けたため、一次共振が生じたと考えられる。このため 応答振幅は自由水が存在しない場合に比べて 2 倍近い傎を示している。図12-aに(a)の場合の横摇れ角変位 の時系列老比較したものを示す。

次に(b)の場合について述べる。外力の振動数が振動系の固有振動数の $n$ 倍 ( $n$ は 2 以上の整数) 付近のとき、 外力の振動数の $1 / n$ 倍の振動数を有寸る振動が生じる場合があり、n次の分周波共振 (subharmonic resonance) と呼ばれる(12)。この(b)の場合は 2 次の分周波共振に対応する $\left(\omega / \omega_{n}=2.05\right)$ 。のため図11におい てロ印で示された自由水が存在する場合の応答值は、強制波の角周波数心が一次同調角周波数を越えてから 一度減少傾向を示しているが、2 次の分周波共振角周波数付近で再び増加し、自由水の存在しない場合よ り大きな值を示している。図12-bに(b)の場合の横摇れ角変位の時系列を比較したものを示す。この図に示 


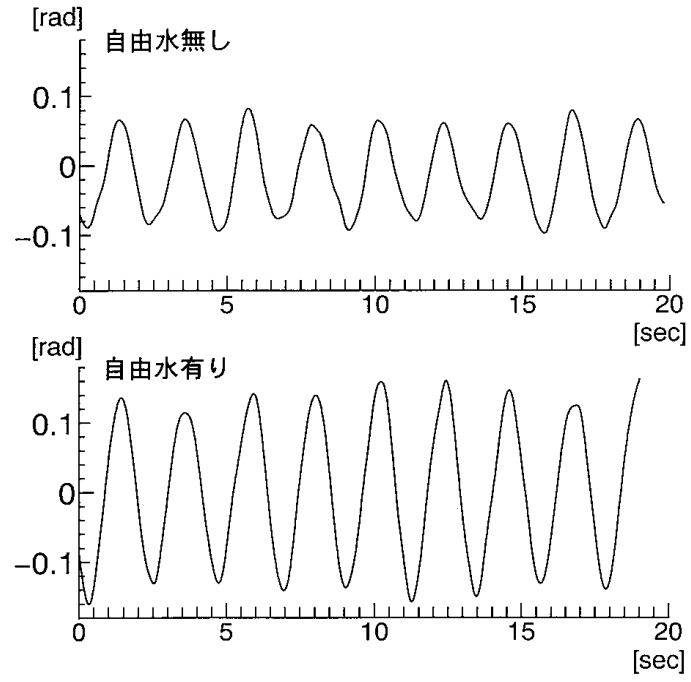

困12-a $\mathrm{a}$ の場合に対応する横摇れ角変位の時系列

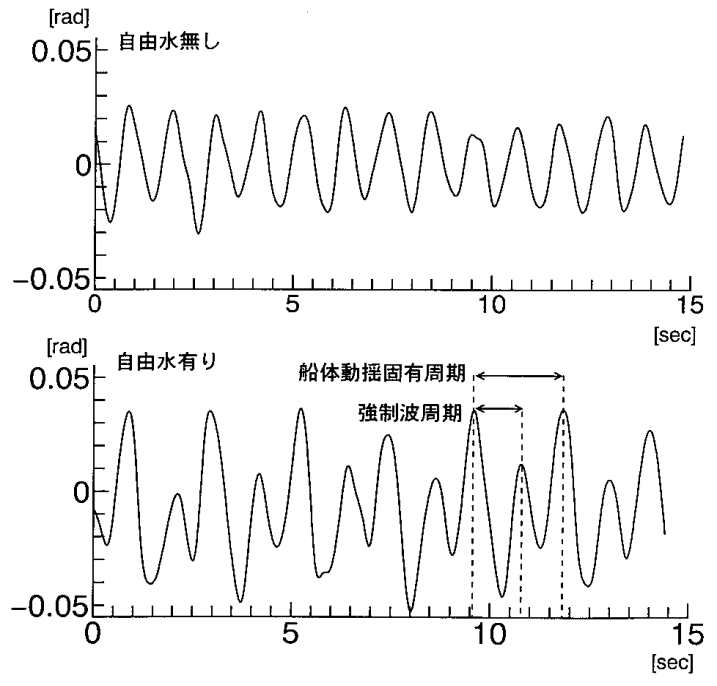

困12-b bの場合に対応する横摇れ角変位の時系列

されているように、強制波の 2 倍の周期 $(1 / 2$ の周波数) を 有する動摇がこの場合生じていることがわかる。

4.3 横摇れと船首摇れとの連成

以上の節では、甲板上に自由水が存在する場合の内で、 減摇効果が作用しない場合について述べなが、本節では 自由水による減摇効果が作用する場合における横摇れと 船首摇れとの連成について論じる。

横運動の連成を考えるうえで、従来船首摇れの影響は、 横摇れに対して非常に小さなものであるとされ、横摇れ。 左右摇れの連成に比べ無視される場合が多い。しかし自 由水による減摇効果が大きく作用する場合に船首摇れの 影響が無視できない場合があることが確認された。以下 「丸東丸」モデルによる典型的な例について述べる。

怅13は波高 $22.3 \mathrm{~cm}$ 、周期 $1.53 \mathrm{sec}$ 強制波を与えた時の 横摇れ角変位と船首摇れ角変位の時系列で自由水が存在 しない場合とする場合を比較したものである。また図14 はこの場合の横摇れと船首摇れの相互相関係数を示して いて、タイムラグてが正であることは横摇れの変動が船首 摇れの変動に先行していることを示す。

自由水が存在しない場合は、横摇れに対する船首摇れ の影響は小さく、位相差も大きくはない。一方、自由水 が存在する場合は横摇れは自由水による減摇効果により 抑制されているが、横摇れに対する船首摇れの影響は無 視できない。また横摇れと船首摇れの間に大きな位相の ずれが生じ、横摇れに対して船首摇れは時間的な遅れる 有している。この顕著な船首摇れの原因としては、甲板 上に自由水が存在することによる艄艉方向の重心位置の

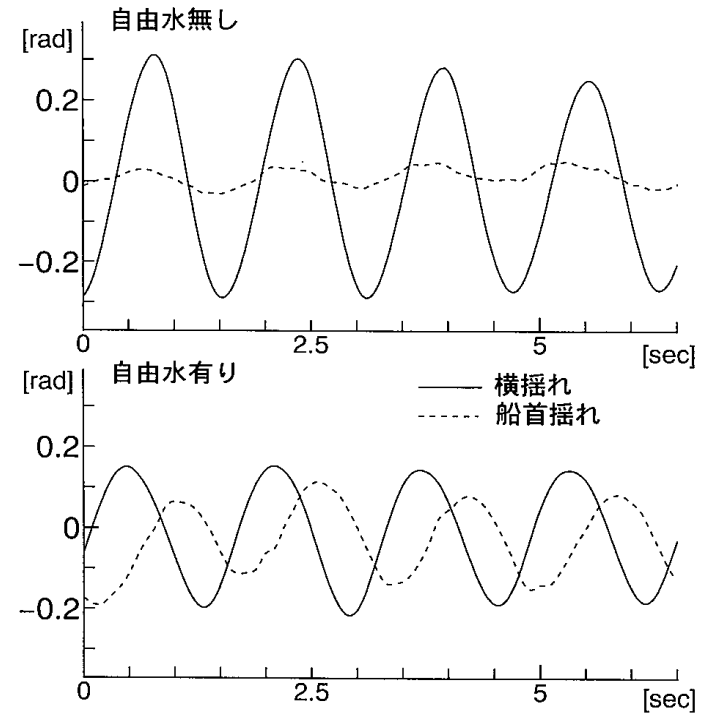

図13 自由水が存在する場合の横摇れ・船首摇れの連成

相互相関係数

自由水有り

自由水無し

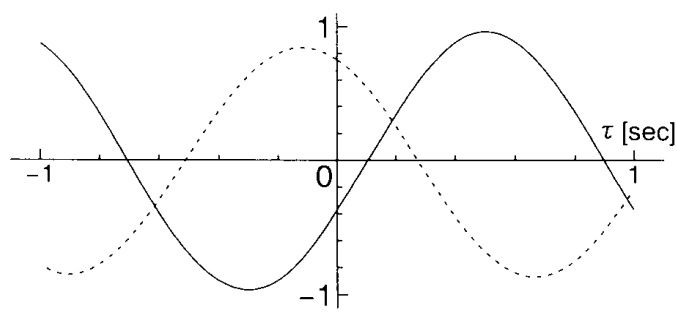

図14 自由水が存在する場合の横摇れ・船首摇れの相互相関 変化と横摇れ回転軸の艄艉への傾斜 ${ }^{(13)}$ そてタンク内で

生じる激しいスロッシングの影響なぼが考えられる。またこの横摇れと船首摇れの間の位相差はタンク内 水の動摇と船体の動摇の位相差等によるものだと考えられる。この横摇れに対して船首摇れは時間的な遅 れを有する傾向は、本実験において自由水による減摇効果が大きく作用した全ての場合において確認され た。 


\section{5. 結言}

1.「北進丸」モデルを用いた自由横摇れ減衰試験より次のような結果を得た。甲板上のタンク内自由水の 固有周期が小振幅時の船体動摇周期よりも長い場合、船体動摇周期は動摇振幅が減少するとともに短くな る傾向を示し、他方甲板上のタンク内自由水の固有周期が小振幅時の船体動摇周期よりも短い場合、船体 動摇周期は動摇振幅が減少するとともに長くなる傾向を示す場合があることが確認された。

2.「北進丸」モデルを用いた規則波中動摇試験において強制波の周期が甲板上のタンク内自由水の固有周 期の $1 / 2$ ( 2 次同調周期) 付近の值のとき、甲板上の自由水の減摇効果はあまり生じず、自由水が存在しない 場合と比較してむしろ動摇振幅が大きな值を示す場合があることが確認された。

3、「丸東丸」モデルを用いた規則波中動摇試験において、甲板上の自由水の存在により動摇周期が変化し、 共振域が移動する。このため強制波の周波数がこの状態の一次共振周波数付近及び、2 次の分周波共振周 波数付近に至ったとき自由水が存在しない場合と比較して動摇振幅が大きな值を示す場合があることが確 認された。

4.「丸東丸」モデルを用いた規則波中動摇試験において、自由水による減摇効果が大きく作用する場合に 横摇れに対する船首摇れの影響が無視できない場合があることが確認された。

\section{6. 謝 辞}

本研究に協力してくれた、北海道大学水産学部 4 年生(研究当時)の長利孝志・深江宏司の両君に感謝しま す。

参 考 文 献

（1）上野会彦・天下井清・木村暢夫・甫喜本司：大角度動摇するタンク内浅水の挙動についての実験と数 值解析 日本航海学会論文集, 第90号, pp.201-213, 1994.

（2）上野会彦・天下井清・木村暢夫・岩森利弘：小型漁船の横摇れ減衰の特徵と推定法について 日本航 海学会論文集, 第93号, pp.149-161，1995.

（3）上野公彦・天下井清・木村暢夫・岩森利弘・下川伸也：自由水を考慮した小型漁船の横摇れ減衰の特 徵について 平成 8 年度日本水産工学会学術講演会論文集, pp.87-92, 1996.

(4) Jeff.Dillinghm: Motion Studies of a Vessel with Water on Deck Marine Technology,Vol.18,No.1, pp.38-50,1981.

（5）吉岡 勲·鈴木勝雄：動摇している水槽内の浅水に生ずる波について（その 1 非線形理論）日本造船 学会論文集，第123号，pp.96-109，1968.

（6）吉岡 勲・鈴木勝雄・関 雅之：動摇している水槽内の浅水に生ずる波について（その 2 非線形理論 - 一補訂） 日本造船学会論文集，第128号，pp.167-177， 1970.

（7）吉岡 勲・平山次清・山越康行：動摇している水槽内の浅水に生ずる波について（その 3 実験） 日本 造船学会論文集，第129号，pp.55-65，1971.

（8）森田知治・生司邦昭：船体動摇による船内水の挙動について一I，一段波発生に関する考察一 日本 航海学会論文集，第78号，pp.121-127，1987.

(9) J.E.Welch,F.H.Harlow,J.P.Shannon,B.J.Daly: "The MAC Method -A Computing Technique for Solving Viscous, Incompressible, Transient Fluid-Flow Problems Involving Free Surfaces" Los Alamos Scientific Laboratory Report LA-3425, 1968.

(10) A.A.Amsden,F.H.Harlow: "The SMAC Method: A Numerical Thecnicque for Calculating Incompressible Fluid Flows" Los Alamos Scientific Laboratory Report LA-4370, 1970.

(11) C.W.Hirt,B.D.Nichols,N.C.Romeo: "SOLA - A Numerical Solution Algorithm for Transient Fluid Flow" Los Alamos Scientific Laboratory Report LA-5852, 1975.

(12) J.J.Stoker: "Nonliner Vibrations" ,INTERSCIENCE 1966.

(13) 質疑応答の欄老参照 


\section{質 疑 応 答}

定兼廣行 (神戸商船大学)：タンク水の存在によって艄摇れが発生したとのことですが、これは甲板上にタ ンクを置いたことによる回転(横摇れ)軸が艄艉に傾斜したのが原因でしょうか。

上野公彦：貴重な御意見を頂きまして有り難うこざいます。実験は自由水が存在しない状態のときもタン クは空のまま設置して行いましたのでタンクの重量による影響は小さいと思われますが、御指摘のよう に甲板上に水が存在することにより、回転(横摇れ)軸が䚀艉に傾斜したことは十分に考劣られます。こ の解釈は本文中においても引用させて頂きました。 